\title{
Early Atlantic Navigation: Pre-Portuguese Presence in the Azores Islands
}

\author{
António Félix Rodrigues', Nuno O. Martins ${ }^{2,3}$, Nuno Ribeiro ${ }^{4}$, Anabela Joaquinito ${ }^{4}$ \\ ${ }^{1}$ Department of Agricultural and Environmental Sciences and CITAA-A, University of the Azores, Angra do \\ Heroísmo, Portugal \\ ${ }^{2}$ Department of Economics and Business Management, University of the Azores, Angra do Heroísmo, Portugal \\ ${ }^{3}$ CEGE-UCP, Oporto, Portugal \\ ${ }^{4}$ Portuguese Association of Archaeological Research (APIA), Oeiras, Portugal \\ Email: felix@uac.pt
}

Received 14 May 2015; accepted 11 July 2015; published 15 July 2015

Copyright (C) 2015 by authors and Scientific Research Publishing Inc.

This work is licensed under the Creative Commons Attribution International License (CC BY).

http://creativecommons.org/licenses/by/4.0/

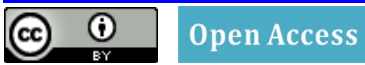

\begin{abstract}
We present here evidence of pre-Portuguese presence in the Azores Islands, Portugal, found near the site of Grota do Medo (Posto Santo), discovered by Rodrigues (2013) in Terceira Island, Azores. This evidence was dated by Accelerator Mass Spectrometry, and indicates the presence of human activity in Terceira Island before or during the $\mathrm{XI}^{{ }^{\text {th }}}$ century. The evidence consisted in a man-made rock basin, which was found in a site that contains also striking similarities with many other aspects from ancient cultures, including other man-made rock basins, arrangements of large stones which resemble megalithic constructions, and inscriptions in stones which resemble ancient petroglyphs. Although the dating of this evidence is highly suggestive of the presence of human activity in the Azores Islands long before the arrival of the Portuguese navigators of the $\mathrm{XV}^{\text {th }}$ century, there is no clear evidence which enables us to identify which specific culture may have existed in the Azores before the Portuguese arrival.
\end{abstract}

\section{Keywords}

Pre-Portuguese Presence in the Azores Islands, Early Atlantic Navigation, Archaeological Dating, Rock Art, Megalithic Constructions

\section{Historical Background on the Discovery of the Azores}

The Azores are nine islands situated in the North Atlantic, divided in three different groups: the Eastern group (constituted by the Island of São Miguel and the Island of Santa Maria), the Central Group (constituted by the 
Islands of Terceira, São Jorge, Pico, Faial and Graciosa), and the Western Group (constituted by the Islands of Flores and Corvo).

The discovery of the Azores is an extraordinarily controversial topic. There is a lack of solid evidence concerning the circumstances surrounding the discovery of the islands. Thus, any discussion of the topic must be undertaken with great caution and modesty. The evidence concerning the first Portuguese navigator to come to the Azores, for example, has been an object of much discussion. Reports from Diogo Gomes, Martins Behaim, Valentim Fernandes or Gaspar Frutuoso point towards the role of Gonçalo Velho in the first travels to the Azores in 1431 and 1432 (Peres, 1962).

However, a chart made by Gabriel de Valsequa in 1439 includes a reference to who discovered the islands that challenges this claim. The chart is not in very good conditions, and the surname of the discoverer of the islands that appears in this chart is extremely difficult to read. The surname has been read as "Guulen", "Sevilla", "Sunis" and "Senil". Peres (1962), who describes this dispute in detail, suggests that we should read these seven lines as "Silves", and attributes to Diogo de Silves the discovery of the islands. But clearly, the interpretation of this word involves a large amount of guesswork.

Portuguese historiography has been much concerned with finding the Portuguese navigator mentioned in the document above, but little effort has been made for understanding whether the islands had already been found when the Portuguese explored them in the $\mathrm{XV}^{\text {th }}$ century. Effectively, the very word "discovery" (in Portuguese, "descoberta") used in some Portuguese documents is subject to interpretation too. As Reis Leite (2012) explains, "descobrir" (i.e., "to discover") may not mean, in the historical context at stake, "to find", which is denoted by the Portuguese word "achamento" instead. "To discover" ("descobrir") could simply mean, in the historical documents, to further explore something that had already been found before. Indeed, maps from the fourteenth century include islands in the North Atlantic located near the geographical locations where the Azores islands stand, such as in a Catalan Atlas from 1375. The Medici-Laurentian Atlas (1351) also seems to show the location of the Azores, being the first to do so (Fisher, 1886). But as Carita (2004) explains, the geographical position of the islands there is not yet the exact location of the Azores, as it appears for example in the chart made by Gabriel de Valsequa in 1439. However, a 1435 map from the Genovese Battista Beccario refers to the Azores islands as the islands "once again found", which suggests again that the Azores had already been found before the Portuguese went to explore them.

Effectively, in some fourteenth century maps we find islands with such names as "corvi marini", which resembles the name "Corvo" (an Azorean island "discovered" by the Portuguese Diogo de Teive together with the island of Flores only latter than the other islands, in 1452), and "S. Zorzi", which resembles the name S. Jorge, as Mendonça (2000) explains. Names like "Brazir", also occur, which are very similar to the name of a peninsula in Terceira Island, called "Monte Brasil" ("Monte" meaning "Mount"). Brasil, one may add, may be read as "enchanted" in Gaelic. The Hy-Brasail of the Irish is a part of the Atlantis of Plato, and in the Pizigani's map of 1367, there appear three islands of this name, two off the Azores and one off the Ireland (Higginson, 1898). Effectively, those islands are part of the medieval imaginary, which includes also much fantasy about these islands.

However, this inclusion of fantasy in the medieval stories about the islands is natural given the medieval attitude towards the sea, where the sea was imagined to be the place where most formidable prodigies and monstrosities take place, as Mattoso (2009) explains. The overall medieval context is one where references to fantastic or enchanted elements are naturally included. So when a story is transmitted through oral tradition through the Middle Ages, those elements will be added to the story naturally, and need not imply that the stories concerning Atlantic islands (in similar locations to where the Azores islands are) contain no elements of truth.

Furthermore, there is much information concerning previous voyages in the Atlantic before the Portuguese gained control of the spice trade in the Indian Ocean. As Cunliffe (2001) explains, the very formation of a Celtic identity in the Bronze Age emerged also because of Atlantic navigation, involving the British Isles and the Iberian Peninsula, leading to the emergence of an Atlantic façade that connected Northern Europe to the Mediterranean. In this period the exchanges and contacts between the Mediterranean populations and the Atlantic populations were intensified, due to the exploitation of tin in the British Isles and across the Atlantic seaboard, in the area which is now Portugal, and copper in southwest part of the Iberian Peninsula (today southern Portugal), metals that were intensively searched by the Bronze Age Mediterranean populations (Ponce, 2013).

There is actually Portuguese historiographical evidence of earlier voyages to the Azores. The sixteenth century Portuguese writer Damião de Góis refers to a statue of a horsemen pointing westwards, found in the island of Corvo, the smaller of the Azorean islands. The statue was broken when an attempt was made to bring it to the Portu- 
guese mainland. As Carita (2004) explains, this story cannot be merely dismissed as a legend, given the credibility, authority and reputation of Damião de Góis within the Court of the Portuguese King John III (D. João III).

Menzies (2002) also mentioned the "legend" of the statue of the Corvo horsemen pointing to westwards and the inscriptions at the bottom "in a writing which we could not understand" to conclude that the people who carved the horse and writing were clearly not European. For Menzies (2002) the confirmation that the Corvo horsemen was a Chinese statue perhaps of the "Emperor on Horseback" Zhu Di, is that the Azores appears on the Chinese/Korean Kangnido chart, produced before the Portuguese discovered of the Islands.

Hispano-Carthaginian coins have also been found in Corvo in 1749 (Podolyn, 1778; Humboldt, 1881; Agostinho, 1946).

Subsequent archeological studies in the 80's made by Isserlin (1984) on the Corvo Island have detected ceramic materials with similarities with Punic ceramics, but those materials were not dated. Later on, Ribeiro et al. (2011, 2012) presented archaeological data from Corvo and Terceira Islands where they mention the discovery of hypogeal structures and an ancient inscription near the site discovered by Rodrigues in 2013 (Rodrigues, 2015).

One of the most important Azorean historians, Drummond (1981 [1850]) also refers to evidence of previous human settlements in the Azores islands, namely in Terceira Island. Some oral tradition, reported by Gaspar Frutuoso (another key Azorean historian), reports that a Greek sailor, caught by a storm after leaving Cádiz, reached the Island of S. Miguel in 1370, as Carita (2004) notes.

The very name “Azores” is a source of much controversy. In Portuguese, "açores” denotes a type of hawk which, according to historiographical and oral Azorean tradition, was found in the islands as soon as the Portuguese first arrived. According to this historiographical and oral Azorean tradition, which is the dominant one, the Portuguese sailors named the islands after this bird which they found in great numbers. There is some controversy about which specific species of hawk this was. It could have been not "açores” (Accipiter gentilis), but rather "milhafres" (Buteo buteo ssp. rothschildi), a different endemic sub-species of hawk that is still common in the Azores today.

But the presence of hawks in great numbers, be they "açores" or "milhafres", indicates the presence of the animals they prey in great numbers too, most notably rodents. However, rodents were introduced in the Azores by human activity, which seems to mean that there had been human beings in the Azores when the Portuguese sailors first came and saw hawks flying around the islands. In fact, a recent study by Gabriel et al. (2013) found that the house mouse in the Azorean islands of Terceira, Flores and Santa Maria and in the Portuguese Island of Madeira too, is genetically different. They conclude that the house mouse found in Terceira, Flores and Santa Maria has genetic characteristics which points towards the Atlantic northern Europe as their origin, which means that there were incursions coming from Atlantic northern Europe before the Portuguese trips. They also note that, according to Kelley (1979) there are indications that the Norwegian Vikings may have visited the Azores, adding another set of questions concerning pre-Portuguese voyages to the Azores. However there may be others explanations related with several commercial contacts during the proto-history or in the Roman period, given the existence of contacts between northern Europe, southern Europe and North Africa in prior periods. We can find, for example, evidences of Roman occupation in the Canary Islands and on the Atlantic coast or in the ancient province of Mauritania (Millán León 1998).

Clearly, discussions concerning who first navigated to the Azores are surrounded by much controversy. These discussions must also be undertaken with a willingness to face the evidence, including new evidence that arises and may challenge, or help interpreting, previous historiography. Here we will provide another piece of evidence, which supports the hypothesis that the Azores, or at least Terceira island, were indeed inhabited long before the Portuguese arrived. This piece of evidence was found near the Grota do Medo (Posto Santo), discovered by Rodrigues (2013), a grove, which contains many elements that possess striking similarities with several aspects from ancient cultures, including man-made rock basins, arrangements of large stones which resemble megalithic constructions, and inscriptions in stones which resemble ancient petroglyphs engraves (Rodrigues, 2015). The site has been in the past a possession of the Portuguese Jesuits who, as is well-known, travelled to locations which did possess similar elements. And the Jesuits came to Terceira Island much after the Franciscan monks, who also travelled through locations with similar elements, and even constructed a church with megalithic features in the Portuguese mainland. However, the absence of any Christian symbols, and the rudimentary technique used in the constructions found in Terceira Island, seems to point towards a different historical context. The evidence we present now indicates that the site had human presence at least since the $\mathrm{XI}^{\text {th }}$ century, and most likely before that too, as we shall show now. 
Figure 1 is part of the topographic map of Terceira Island and shows the location of the dated structure and megalithic constructions (Rodrigues, 2015) which are currently not explained by the Azorean historiography, mentioned above.

\section{Sample Genesis and Experimental Confirmation of Packed Micro-Crystals of Silica Formation from an Acid-Digested Trachyte Rock}

A man made bowl (small container excavated in the rock, associated with channels) was found at an outcrop at Terceira Island, Azores, Portugal on a trachytic rock. A solid wall made of silica layers with a total thickness of $3 \mathrm{~cm}, 6 \mathrm{~cm}$ height and $36 \mathrm{~cm}$ width was found blocking the front of this bowl. The presence of amorphous silica in soils and altered rocks is very common on volcanic islands, such as the Azores, and can also appear on trachytic rocks (see Rodríguez-Clemente \& Tardy, 1986).

It was important to assure that the study bowl from where the sample was taken was man-made. The bowl geometric form is not rounded, nor square: the flat front wall is $36 \mathrm{~cm}$ width, the distance from the front wall to the back wall is $52 \mathrm{~cm}$ and the distance between the lateral sides of the cup is $45 \mathrm{~cm}$. This form could not be explained for any kind of erosion process, which means that it is indeed man made.

Trachyte's are igneous volcanic rocks with aphanitic to porphyritic textures, whose minerals do not have time

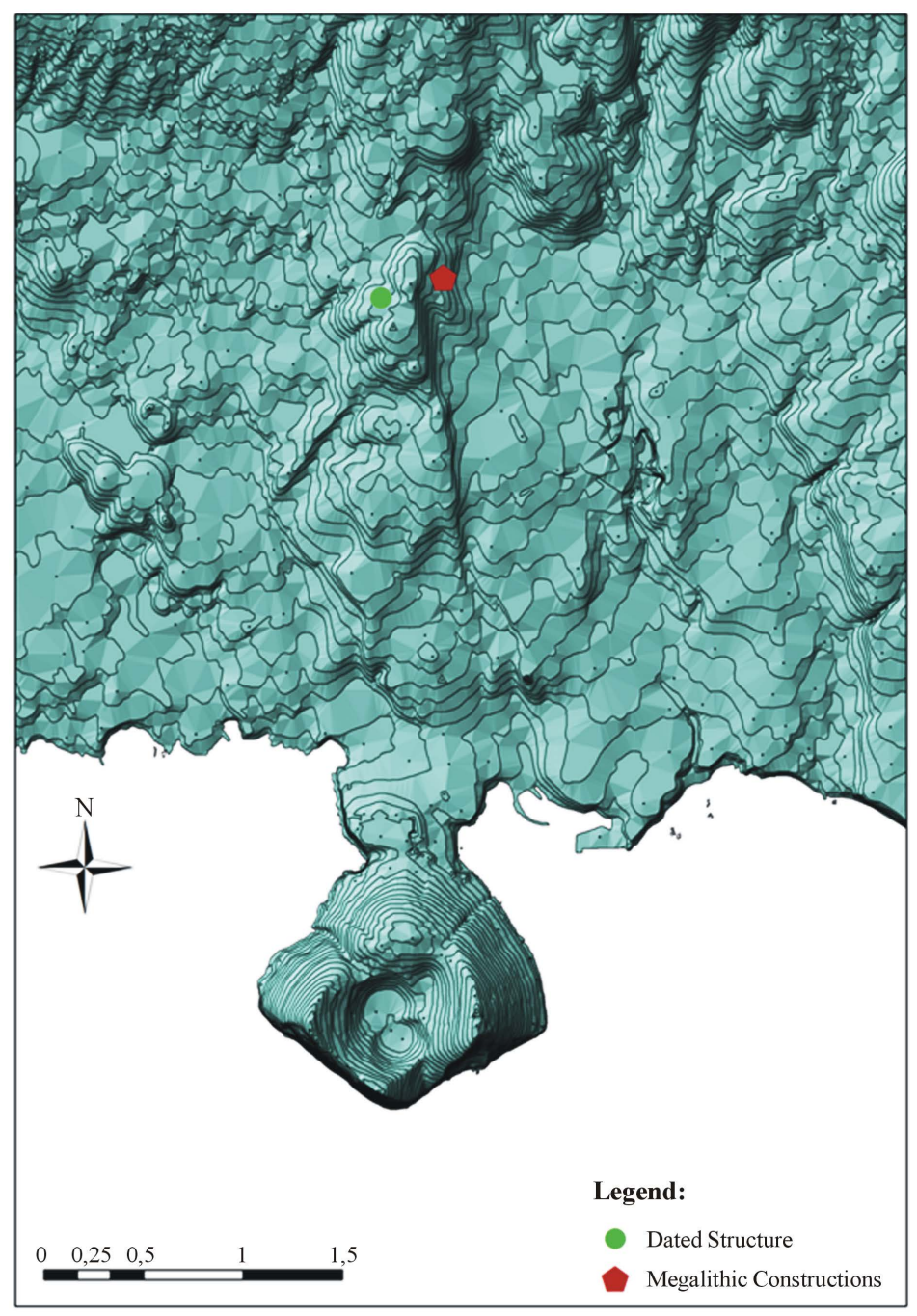

Figure 1. Map showing the location of the sites with human structures not-explained by the historiographic Portuguese paradigm (Isolines with a contour interval of $5 \mathrm{~m}$ ). 
to form large crystals since the fast cooling causes the fast crystallization of the rest of the melt rock into smaller imperfect boards, forming a thinly crystalline groundmass. Those mineral masses consist essentially in alkali feldspars; relatively negligible plagioclase and quartz. Biotite and olivine are also common in trachyte's (Tarbuck \& Lutgens, 2002), but not in the Pico do Espigão, where the studied bowl was found.

Some volcanic rocks might provide favorable conditions for the fossilization of terrestrial life because they contain fine-disperse silica which is leached by rainwater and precipitated at the decaying organic matter trapped below. Felsic glasses have elevated $\mathrm{K}_{2} \mathrm{O}, \mathrm{Na}_{2} \mathrm{O}, \mathrm{Al}_{2} \mathrm{O}_{3}$ and $\mathrm{SiO}_{2}$ concentrations. Of the oxides, the silica $\left(\mathrm{SiO}_{2}\right)$ is usually the most abundant contents on trachyte and other volcanic rocks. White (1983) reported selective partial removal of sodium ( $\mathrm{Na}$ ), potassium (K), and aluminum ( $\mathrm{Al}$ ) into solution in experiments at $25^{\circ} \mathrm{C}$ on felsic glasses, and suggest that silica release into solution results from congruent dissolution. The congruent dissolution of silica is an intricate chemical system to explain.

According to Bridge \& Demicco (2008) at normal shallow subsurface groundwater $\mathrm{pH}$, the dissolution reaction of quartz is given by the chemical equation:

$$
\mathrm{SiO}_{2}(\text { quartz })+\mathrm{H}_{2} \mathrm{O} \stackrel{25^{\circ} \mathrm{C}}{\Leftrightarrow} \mathrm{H}_{4} \mathrm{SiO}_{4}(\text { aq })
$$

and yields non-ionized silicic acid $\left(\mathrm{H}_{4} \mathrm{SiO}_{4}\right)$. With an increase of $\mathrm{pH}$ of alkaline water the solubility of quartz and of the amorphous silica is greatly improved (Bridge \& Demicco 2008).

If the leaching of silica in a trachytic bowl, full of rainwater, continues for a long time, a mineral deposit will be formed in the bottom of the bowl. The deposit of organic matter (by vegetation) above the stagnant water takes place during the same period, together with the development of larvae, bacteria's and a great diversity of small insects. This deposited organic matter in a solution of amorphous silica where trapped inside the silica layers when formed at the bottom of the trachytic bowl.

There are ranges of parameter sets (silica concentration, $\mathrm{pH}$, salinity, temperature, etc.) in which silica solutions are supersaturated, tending to a gel formation. The super-saturation usually takes place by temperature decrease, which can occur especially by night or through lowering the $\mathrm{pH}$ of the solution. When the growth of the precipitates results in a stage of tightly packed micro-crystals, with no gel left, a solid cement-like is obtained.

An experiment was made at the Physics Laboratory in the University of the Azores, digesting a trachytic rock sample into a solution of sulfuric acid. This procedure corresponds to lowering the $\mathrm{pH}$ of water solution. After dehydration of the formed precipitates, six months later, tightly packed micro-crystals of silica where formed.

Usually the hydration of alkali silicate glasses, present in the trachytic rocks, in aqueous solution is accompanied by $\mathrm{Na}^{+}-\mathrm{H}_{3} \mathrm{O}^{+}$inter-diffusion. According to Bunker et al. (1983) the process is greatly enhanced in solutions with constant low $\mathrm{pH}$, where an abundance of $\mathrm{H}_{3} \mathrm{O}^{+}$ions is available for exchange with $\mathrm{Na}^{+}$at the glass-water interface. The rainwater $\mathrm{pH}$ in the Azores is near 6.7 (Rodrigues et al., 2002), and is not sufficiently acid for producing the $\mathrm{Na}^{+}-\mathrm{H}_{3} \mathrm{O}^{+}$inter-diffusion. However, the water in volcanic Azorean soils has a $\mathrm{pH}$ around 5.5 to 5.7 (Amaral et al., 2006) making it possible to generate the mentioned cationic exchange.

The physical and chemical principles mentioned above made us suspect that between the tightly packed micro-crystals of silica of the bowl wall there was enough organic matter for dating by Accelerator Mass Spectrometry (AMS).

\section{Sampling and Structure Description}

A sample of $97 \mathrm{~g}$ of silica cement, from the front wall of the man-made cup in the trachytic rock of Terceira Island, Azores, Portugal, was collected directly into a ziplock bag and sent to Beta Analytics laboratory for radiocarbon analysis.

The black arrow of Figure 2 shows the place of the wall from where the cement sample was taken.

The sample was treated with acid and alkali solutions, according the procedures of the Beta Analytics Radiocarbon dating.

The carbon present in the sample was sufficient for accurate measurement by the laboratory. The sample analysis was performed entirely in the Beta Analytics laboratories according to ISO-17025 standards.

In this man-made bowl we found rock art or symbols surrounding the cup. At the left side: a small oval hole with a channel, a sign with a V shape and a stroke are perceived, which could too be related with ancient cultures [see (Harrod, 1998)]. On the top of the bowl, a meander has found and at the left side, a possible arc or part of a spiral was observed (see Figure 3 and Figure 4). 


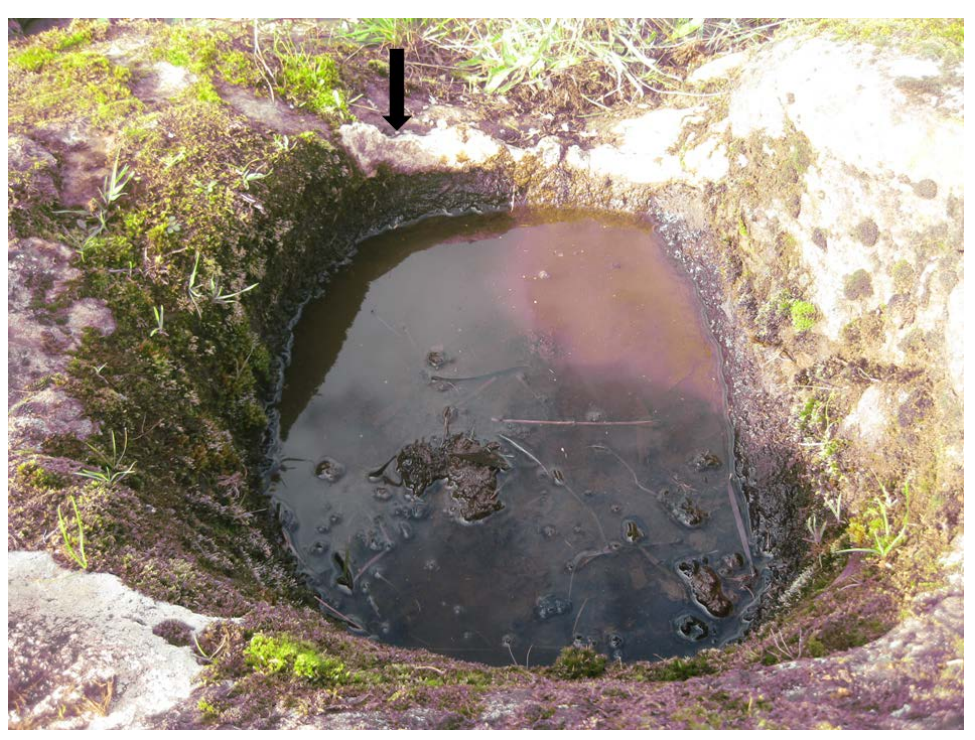

Figure 2. Man-made bowl with, in front, white wall made of silica layers from where the cement sample was taken.

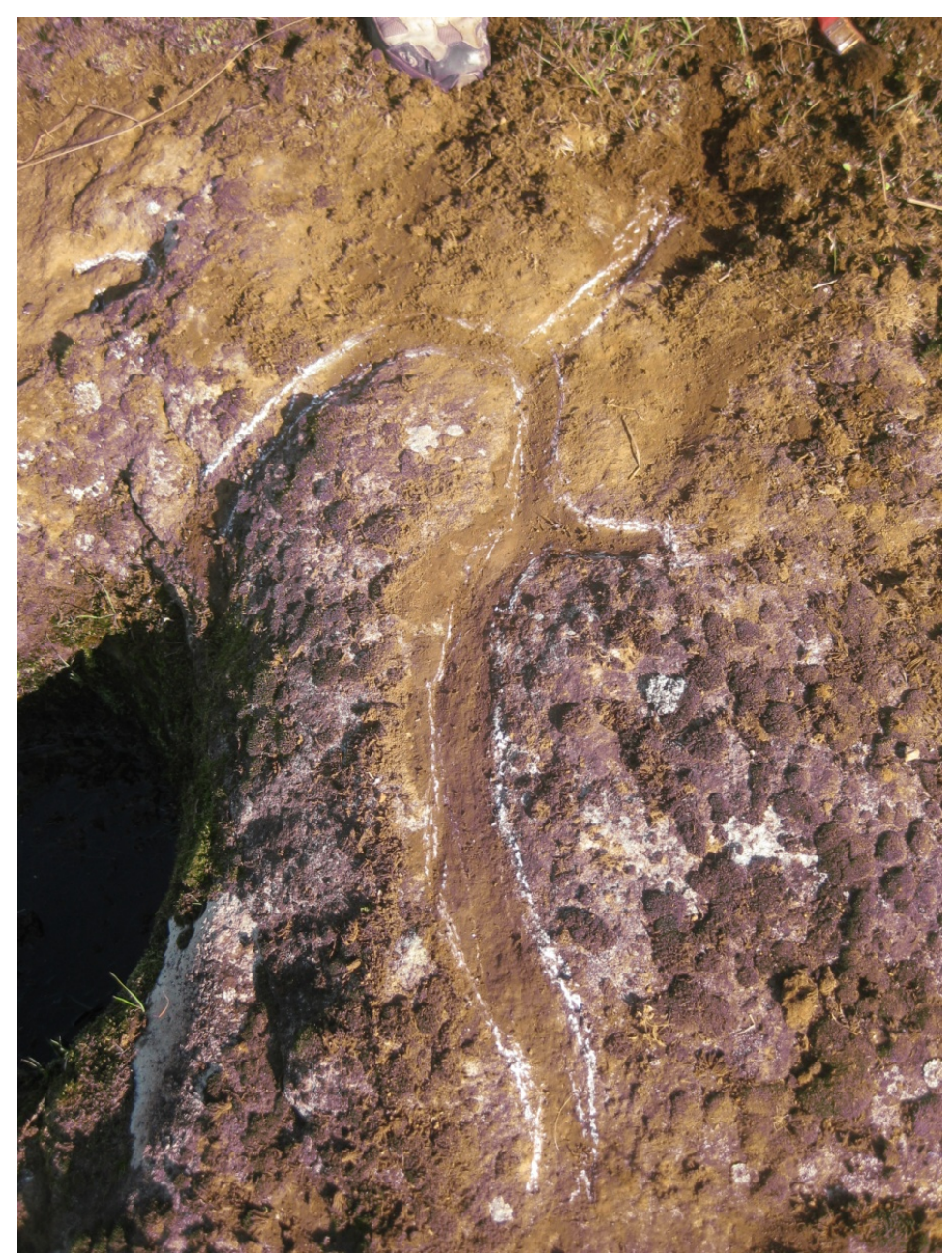

Figure 3. Channel or serpentiform symbol, with similarities with ancient European protolanguage. 


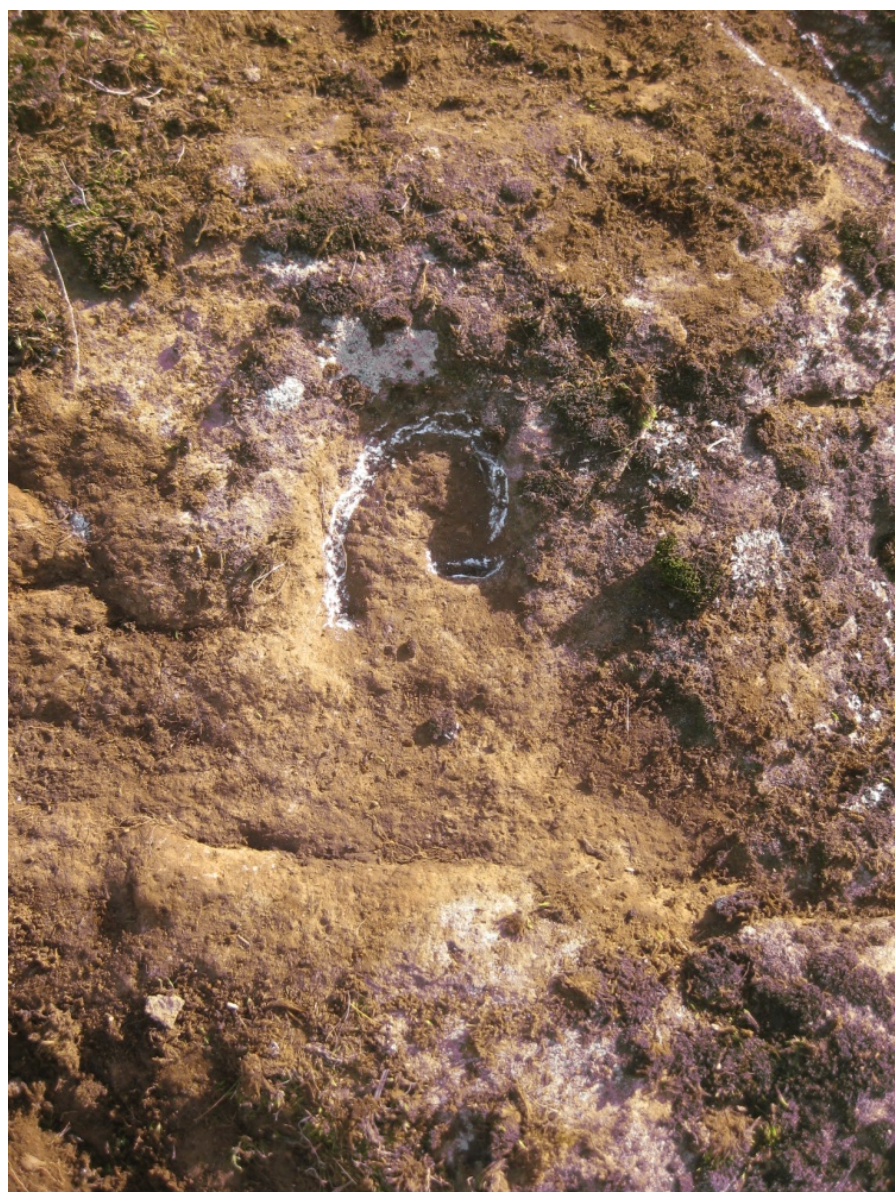

Figure 4. Possible symbol with arc shape or part of a spiral, engraved on the Azorean study man-made bowl.

Harrod (1998), referring to the ancient European cultures says that meanders where related to a water mythology and rituals, and reports this kind of symbols to an ancient European protolanguage.

This bowl is engraved with both a pair of geometric signs and iconic imagery which itself seems to be paired with the ancient European symbols, and it is very difficult, or almost impossible, to establish parallels with known Portuguese ethnographic sources in the Azores.

Figure 5 shows a plan-view mapping from the study stone, where all details like symbols, channels, bowl, natural rock fractures and limits of the stone where recorded. The numbers marked on the chart, preceded of the minus signal, represents the $\mathrm{z}$ coordinate.

Summarizing the symbols that where founded on the study structure with the dated bowl, based on the work of Harrod (1998), it was found: a) an oval hole, a possible vulvalike shape with a channel; b) a possible arc or part of a spiral; c) a V shape; d) an oblique stroke, and e) a meander or channels.

\section{Dating Results and Concluding Remarks}

The Measured Radiocarbon Age of the sample, by the Accelerator Mass Spectrometry Method, was $910 \pm 30$ years before the present (BP) and the Conventional Radiocarbon Age was $950 \pm 30$ years BP.

The Conventional Radiocarbon Age is obtained using a set of parameters outlined by Stuiver \& Polach (1977).

The calibration curves used by Beta Analytics were constructed from the set of ${ }^{14} \mathrm{C}$ ages obtained for samples each spanning a 20 -year or 50-year intervals for one sigma calibration and 140-year interval for two sigma calibration.

The one sigma calibration results (that correspond to a confidence level of 68\%) produced the dates from 


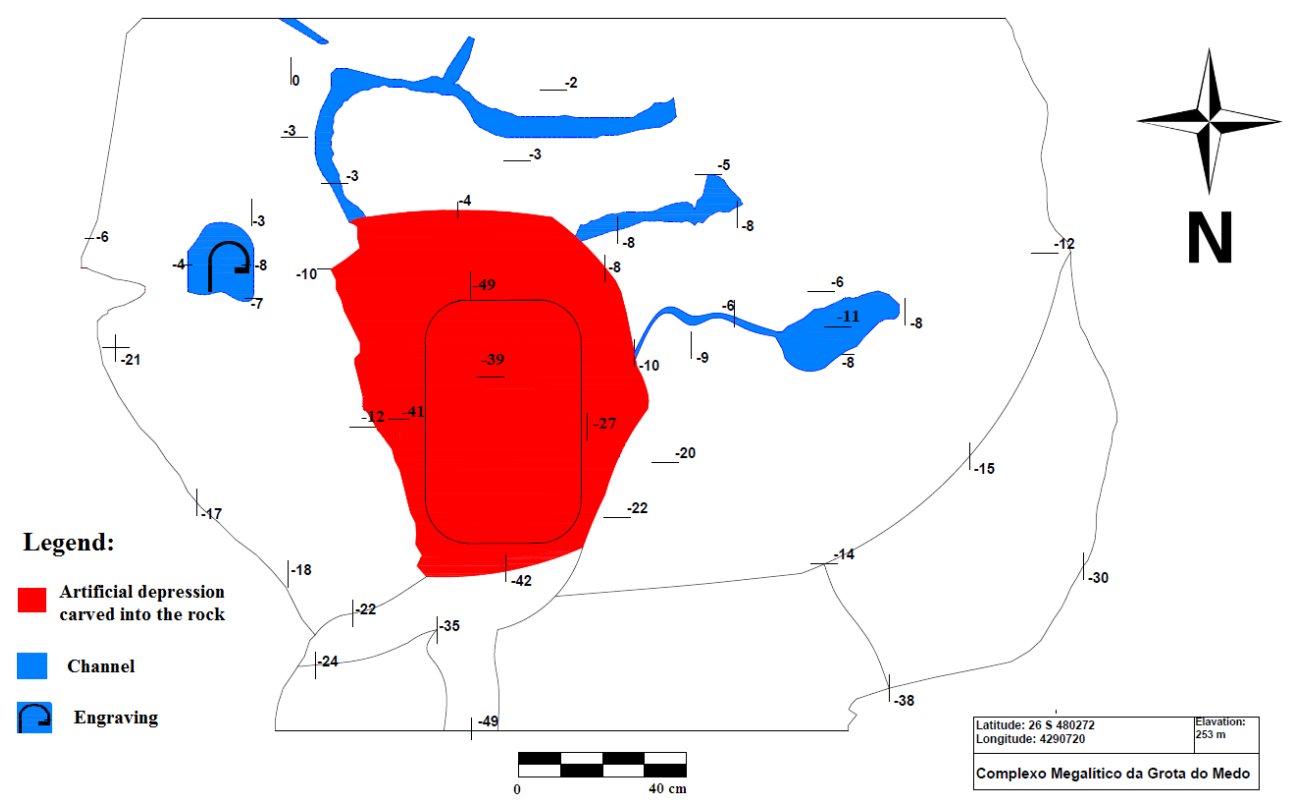

Figure 5. Topographic map of the studied and dated structure (Adapted from Tavares et al., 2014).

AD 1030 to AD 1050 (Cal BP 920 to 900), AD 1080 to AD 1130 (Cal BP 870 to 820) and AD 1130 to AD 1150 (Cal BP 820 to 800). The two Sigma calibrated result (that corresponds to a confidence level of 95\%) produce the dates from AD 1020 to AD 1160 (Cal BP 930 to 790). From the Quality Assurance Report, using four references to validate radiocarbon analyses, we find that all measurements passed the acceptance tests.

The material pretreatment for the extraction of organic material was made with acid and alkali washes. It was assumed that humic and fulvic acids could be the main components of humic substances, which were the major organic constituents of soil (humus) or produced by biodegradation of dead organic matter. In this context, when sediments are treated with alkali, to extract humic acids and then date it, problematic results sometimes occur depending on the soil geochemistry, because the alkali extractions on sediments will remove any unbound carbon that is alkali-soluble. The source of this carbon can be from more recent humic and fulvic acids. Since we found soil inside the bowl, this kind of extraction could produce a less accurate dating of organic matter inside the silica sample. Many times the alkali-extracted sediment yields a more recent date than the real date due to the factors mentioned above.

Based on obtained results it seems reasonable to state that the Azores, (at the moment only Terceira Island), were indeed visited or inhabited at least in the $\mathrm{XI}^{\text {th }}$ Century, long before the Portuguese arrived. It is also possible to infer that visits to the island by humans or human settlements occurred before this date because the date here reported corresponds to the moment when the bowl was broken. It is not possible to know whether the bowl was broken at the moment when it was made, or later. The rock art surrounding the bowl, and the similarities with earlier small sanctuaries in Europe, provide contextual evidence that suggests that the bowl may have been made before the $\mathrm{XI}^{\text {th }}$ Century, or at least appeared within a culture which at this moment possessed similarities with earlier European cultures.

\section{Acknowledgements}

The authors warmly thank two anonymous referees for their suggestions that improved the quality of the original manuscript and the collaboration of the Engineer João Filipe Fernandes. Special thanks also go to Lisa Silva, for her suggestions and revision of the text and for the Angra do Heroísmo City Hall for their support.

\section{References}

Agostinho, J. (1946). Achados Arqueológicos nos Açores. Açoreana, 5, 101-102.

Amaral, A., Cruz, V., Cunha, R., \& Rodrigues, A. (2006). Baseline Levels of Metals in Volcanic Soils of the Azores (Portugal). Soil and Sediment Contamination, 15, 123-130. http://dx.doi.org/10.1080/15320380500506255 
Bridge, J., \& Demicco, R. (2008). Earth Surface Processes, Landforms and Sediment Deposits. Cambridge: Cambridge University Press. http://dx.doi.org/10.1017/CBO9780511805516

Bunker, B., Arnold, G., \& Beauchamp, E. (1983). Mechanisms for Alkali Leaching in Mized-Na-K Silicate Glasses. Journal of Non-Crystalline Solids, 58, 295-322. http://dx.doi.org/10.1016/0022-3093(83)90031-5

Carita, R. (2004). O descobrimento dos Açores. In A. Matos, A. Meneses, \& J. G. Reis Leite (Eds.). História dos Açores. Angra do Heroísmo: Instituto Açoriano de Cultura.

Cunliffe, B. (2001). Facing the Ocean: The Atlantic and Its Peoples, 8000 BC to AD 1500. Oxford: Oxford University Press.

Drummond, F. F. (1981 [1850]). Anais da Ilha Terceira. Vol. 1, Secretaria Regional da Educação e Cultura. Angra do Heroísmo.

Fisher, T. (1886). Sammlung mittelalterlicher Welt-Und Seekarten italienischen Ursprungs: und aus italienischen Bibliotheken und Archiven. Venedig: Ferdinand Ongania.

Gabriel, S., Matias, M. L., \& Searle, J. (2013). Genetic Structure of House Mouse (Mus musculus Linnaeus 1758) Populations in the Atlantic Archipelago of the Azores: Colonization and Dispersal. Biological Journal of the Linnean Society, 108, 929-940. http://dx.doi.org/10.1111/bij.12015

Harrod, J. (1998). Deciphering Upper Paleolithic (European): Part 1. The Basic Graphematics—Summary of Discovery Procedures. Language Origins Society Annual Meeting 1998, Florida State University.

http://www.originsnet.org/loslecture888k.pdf

Higginson, T. W. (1898). Tales of the Enchanted Islands of the Atlantic. New York: Grosset \& Dunlap Publishers.

Humboldt, A. (1881). Examen Critique de la Geographie du Nouveau Monde. Volume III, Facsimile Edition, Ponta Delgada: University of the Azores.

Isserlin, B. (1984). Did Carthaginian Mariners Reach the Island of Corvo (Azores)? Rivista Di Studi Fenici Sommari, 12, 3146.

Kelley, J. E. (1979). Non-Mediterranean Influences That Shaped the Atlantic in the Early Portolan Charts. Imago Mundi: The International Journal for the History of Cartography, 31, 18-35. http://dx.doi.org/10.1080/03085697908592481

Mattoso, J. (2009). Naquele Tempo: Ensaios de História Medieval. Lisboa: Círculo de Leitores.

Mendonça, L. (2000). História dos Açores_Visão Geral (2nd ed.). Ponta Delgada: Nova Gráfica.

Menzies, G. (2002). 1421: The Year China Discovered the World. Ealing: Bantam Press.

Millán León, J. (1998). Gades y las navegaciones oceánicas en la Antigüedad (1000 a. C.-500 d. C.). Écija: Gráficas Sol.

Peres, D. (1962). A História dos Descobrimentos Portugueses (2nd ed.). Porto: Vertente.

Podolyn, J. (1778). Some Notes on the Voyages of the Ancients, Based on Several Carthaginian and Cyrenaican Coins Found in 1749 on One of the Azores Islands. The Göteborgske Wetenskap og Witterhets Samlingar, 1, 106.

Ponce, M. A. (2013). O bronze final na Península de Lisboa: O caso do Cabeço de Alcaiça na transição entre o $2^{\circ}$ e o $1^{\circ}$ Milénio a.C.. Unpublished Master Dissertation, Lisboa: Universidade de Lisboa.

Reis Leite, J. G. (2012). 7 Ensaios sobre o Povoamento dos Açores. Praia da Vitória: Blu.

Ribeiro, N., \& Joaquinito, A. (2012). New Unknown Archaeological Data in Azores: The Hipogea of the Brazil Mount, Terceira Island (Portugal) and Its Parallels with the Cultures of the Mediterranean. Proceedings of the 16th SOMA 2012, Florence, 1-3 March 2012.

Ribeiro, N., Joaquinito, A., \& Pereira, A. S. (2011). Phoenicians in the Azores, Myth or Reality? Proceedings of the 15th SOMA 2011, Catania, 3-5 March 2011.

Rodrigues, A. F. (2013). Megalithic Discoveries in the Azores. Proceedings of the 16th Annual Mediterranean Studies Association International Congress, Angra do Heroísmo, 29 May-1 June 2013.

Rodrigues, A. F. (2015). Megalithic Constructions Discovered in the Azores, Portugal. Archaeological Discovery, 3, 51-61. http://dx.doi.org/10.4236/ad.2015.32006

Rodrigues, A. F., Lobo, A., \& Rego, S. (2002). Acidez da Precipitação da Ilha Terceira-Açores: Possíveis Efeitos na Cryptomeria japonica da Ilha. Proceedings of the 6th Congresso da água. A água é d'ouro-Ameaças, Segurança e Soluções, Porto, 18-22 March 2002.

Rodríguez-Clemente, R., \& Tardy, Y. (Eds.) (1986). Geochemistry and Mineral Formation in the Earth Surface. Proceedings of the International Meeting on Geochemistry of the Earth Surface and Processes of Mineral Formation, Granada, 16-22 March 1986. Consejo Superior de Investigaciones Cientificas. Madrid.

Stuiver, M., \& Polach, H. (1977). Discussion: Reporting of ${ }^{14}$ C Data. Radiocarbon, 19, 355-363. http://www.uni-kiel.de/leibniz/Leibniz-web_deutsch/datierungsergebnisse/Stuiver-Polach.pdf

Tarbuck, E., \& Lutgens, F. K. (2002). Earth: An Introduction to Physical Geology (7 $7^{\text {th }}$ ed.). Upper Saddle River, NJ: Prentice 
Hall.

Tavares, M., Silva, P. C., Botelho, R., Rodrigues, A. F., \& Martins, N. (2014). Transformações geométricas e transformações matriciais. Condições de equivalência num estudo de caso (Levantamento topográfico de uma peça arqueológica do Complexo Megalítico da Grota do Medo-Terceira, Açores, Portugal). Atas do FIPED-Portugal IV, Universidade dos Açores, Angra do Heroísmo, 4 e 5 de abril de 2014.

White, A. F. (1983). Surface Chemistry and Dissolution Kinetics of Glassy Rocks at $25^{\circ} \mathrm{C}$. Geochimica et Cosmochimica Acta, 47, 805-815. http://dx.doi.org/10.1016/0016-7037(83)90114-X 